\title{
National Projects and Feminism: The Construction of Welfare States through the Analysis of the 8M Manifestos of Progressive and Conservative Political Parties in Spain
}

\author{
Luis Navarro Ardoy ${ }^{1, *(1)}$ and Alba Redondo Mesa ${ }^{2,+}$ \\ 1 Sociology Department, Faculty of Social Science, Pablo de Olavide University, Ctra. de Utrera Km. 1, \\ 41013 Seville, Spain \\ 2 Independent Researcher, 06129 Zahínos, Spain; aredmes8@gmail.com \\ * Correspondence: Inavard@upo.es \\ † Graduated in Department of Sociology and Social Work, Pablo de Olavide University, Ctra. de Utrera Km. 1, \\ 41013 Seville, Spain.
}

check for updates

Citation: Ardoy, Luis Navarro, and Alba Redondo Mesa. 2021. National Projects and Feminism: The Construction of Welfare States through the Analysis of the $8 \mathrm{M}$ Manifestos of Progressive and Conservative Political Parties in Spain. Genealogy 5: 82. https://doi. org/10.3390/genealogy5030082

Received: 29 April 2021

Accepted: 30 August 2021

Published: 8 September 2021

Publisher's Note: MDPI stays neutral with regard to jurisdictional claims in published maps and institutional affiliations.

Copyright: (c) 2021 by the authors. Licensee MDPI, Basel, Switzerland. This article is an open access article distributed under the terms and conditions of the Creative Commons Attribution (CC BY) license (https:// creativecommons.org/licenses/by/ $4.0 /)$.

\begin{abstract}
This paper studies the national projects defended by Spanish political parties on the basis of the image they project in relation to women's roles. To do so, we start with a critical review of nations and welfare states as masculinized projects, and from this we design a strategy based on the analysis of the manifestos issued by each political party in 2020 on International Women's Day. The results obtained reflect the existence of three different ways of understanding the nation from a gender perspective: the first bloc, formed by the two conservative parties, PP and VOX, reproduces the nation by basing their discourse on gender inequalities, with a great weight of care for women; the second, formed by the most progressive parties (IU and Podemos), is situated in a clearly feminist perspective; the third, formed by the PSOE, shows a mixture of ideas that is reflected in considering both sexes as political subjects of feminism, and in presenting a discourse of the liberal and socialist current.
\end{abstract}

Keywords: feminism; welfare state; national projects; political parties; gender roles

\section{Introduction}

This paper presents a novel approach to national projects and their construction based on the image projected by Spanish political parties in the manifestos issued in 2020 on the occasion of International Women's Day (8M) in relation to women's roles. To do so, we use a mixed methodology, combining the quantification of concepts with the coding protocol developed by Humlebaek and Ruiz (2018). The choice of the Spanish case as a case study is an excellent opportunity for the analysis of the model of nationhood and feminism, as it allows us to differentiate between two blocks of political parties that correspond to those that form the progressive central government-Partido Socialista Obrero Español (2020) (PSOE), Unidas Podemos and Izquierda Unida (IU)—and the conservative opposition, Partido Popular (PP) and VOX (see Supplementary Materials).

The choice of this theme responds to three issues. Firstly, despite the return of nationalist movements and national identity (Hobsbawn 1988; Márquez 2011), there are few analyses that were conducted from a feminist perspective (McClintock 1995). Secondly, nationalism is mostly focused and dominated by a male and patriarchal perspective, which is reflected in the assimilation of different concepts to define the nation with those gender roles that are typically established (Nagel 1998, p. 242). Thirdly, the great relevance that $8 \mathrm{M}$ has gained in recent years and, with this, the political implication of this day. The messages issued by political parties through $8 \mathrm{M}$ manifestos reflect frames of reference with a clear appropriation of feminism according to the political ideology they represent. On that day, allusions to feminism and the women's roles became one of the main issues on 
the political agenda, with extensive media coverage within the major topics of political confrontation. The choice of 2020 as the year of analysis is justified by the high politicization of $8 \mathrm{M}$. As pointed out by some media, unlike other years, the $8 \mathrm{M}$ in 2020 was much more visible and politicised due to the presence of partisan symbols during the demonstrations (Público 2020). In that year, except for VOX, all of the Spanish political parties analysed here attended and participated in the $8 \mathrm{M}$ demonstrations. For its part, VOX held an event on the same day to combat $8 \mathrm{M}$ attendance. Moreover, 2020 was the only year in which the parties with the largest representation in the Spanish Congress produced an $8 \mathrm{M}$ manifesto (previously, there were always some parties that did not do so).

The aim of this paper is to analyse the national projects defended by Spanish political parties on the basis of the image they project in relation to women's roles. To do so, we use a key unit of information, such as their $8 \mathrm{M}$ manifestos, and an original methodology to achieve these results. To do so, we start from the discussion on the nature of the nation and nationalism, and some useful concepts related to feminism. We approach this research considering feminism as a political discourse based on justice (Varela 2008). From its plurality, it has been taking shape from three interconnected ways of doing things: it is a theory, it is a social and political militancy, and it is an everyday practice, a way of understanding and living life. It is a theory, critical of society, which deconstructs everything we have learned and enables us to have a new vision and interpretation of reality. It is a diverse social and political militancy which, by not being subject to a political party, has made it possible to unite the voices and demands of women, regardless of their other social characteristics, thus creating a "we" as a political subject. It is a way of understanding and living life, as it implies an individual process of personal change, of confronting and dismantling tradition, education and the expectations created about women (De Miguel 2015)

We focus on showing what image of women is projected by each political party in their $8 \mathrm{M}$ manifestos by linking it to positions around care, family, labor rights, gender role division, the feminist movement and the intersectionality of oppressions. Understanding the connection between this set of elements will allow us to recognize the types of welfare nations portrayed (imagined) by political parties through their manifestos. Specifically, our research questions are: (1) to what extent does the conception or currents of feminism appear among left-wing and right-wing political parties on the basis of the image they project of women; (2) what model of the state does each political party construct on the basis of feminism; (3) what discursive strategies do they use to give it its own meaning and possibly differentiate themselves from their opponents? The study is based on the analysis of the five 8M manifestos of the dominant Spanish political parties: on the one hand, the conservative parties VOX and PP; on the other hand, the progressive parties PSOE, IU and Podemos.

This essay makes empirical and analytical contributions. It provides hitherto nonexistent information on the image projected by Spanish progressive and conservative political parties in relation to women's roles in the $8 \mathrm{M}$ manifestos. The method also offers possibilities for replication in other contexts. The analytical contribution consists of an exploration of the dynamics of communication around national projects and feminism in left-wing and right-wing political parties. Understanding the connection between this set of elements can provide food for thought on the types of welfare nations portrayed (imagined) by political parties through their manifestos.

The article is organized into the following sections. In point two (Section 2), we review a critical review of nations and welfare states as masculinized projects. In Section 3, the methodology, the source of the data obtained and the strategy for analysing the information are presented. The following Section 4 presents the results of the analysis of the $8 \mathrm{M}$ manifestos issued by the main Spanish political parties based on a count of keywords related to the model of nationhood presented by each party and feminism (Section 4.1), and the adaptation of the coding protocol developed by Humlebaek and Ruiz (2018) for the analysis of the political community (Section 4.2). Finally (Section 5), the main findings 
are synthesized, and a discussion is given on the role of welfare nationalism and feminism in political parties.

\section{Rethink the Nation}

In this research, the study of the concept of nation under the constructivist perspective allows us to consider the existence of political interests in defining the nation and, from there, to include the gender perspective in the analysis of the type of nationalism constructed by political parties. Thus, beyond its purely administrative or structural dimension, the nation is an "imagined political community" (Anderson 1993; Lepsius 2004) in which we are interested in observing and analysing the style and meaning given to it by different political actors from different political backgrounds (Greenfeld 2005; Smith 2000; Márquez 2011; Martínez 2002).

Mosse (1996, p. 7) argues that modern nationalism and Western masculinity emerged at more or less the same time and place, accompanied by other ideologies such as colonialism or imperialism (Mackenzie 1987; Walvin 1987; Bologh 1990). It was mainly men who adhered to and promulgated these ideologies. For this reason, nationalism and masculinity are shaped by the same cast (Nagel 1998, pp. 243-51). As Pateman (1989) and Connell (1995) argue, nations are understood as masculine projects, where institutions, processes and activities are masculinized, and women have been rendered invisible, acquiring an inferior symbolic role to that of men in nationalist movements (Enloe 1990, p. 45).

Thus, the absence of a gender perspective in these political processes and their implications undermines the understanding of these processes (Kandiyoti 2000a; Hadjipavlou 2006). National projects cannot be separated from the existing hierarchy of power in the subjects that make them up, including gender (Al-Ali 2000; Kandiyoti 2000b; Villellas and Villellas 2007). For this reason, nationalism projects gender roles, rhetoric and symbolism constructed from naturalised gender identities, where women are in a position of structural inequality with respect to men, and where they also help to reproduce them (Kandiyoti 2000b; Hadjipavlou 2006).

McClintock (1993) argues that nations are seen as practices and institutions through which social difference is represented, which are institutions that have historically sanctioned gender difference, giving men and women different rights and resources. As several authors argue, women do not belong to nations in the same way as men. They are not allowed to decide on issues related to the nation; however, it is women's bodies on which the mythology of nationhood is built, as they narrate the origin of the country (Eisentein et al. 2000). These-women's bodies-become instrumental in the delimitation of the nation (Villellas and Villellas 2007).

But nations cannot be understood without women's experiences (Enloe 1990), as nationalism, citizenship and gender are closely related concepts because they play a key role in the construction and maintenance of states (Kaufman and Williams 2017).

The naturalization of the genealogical dimension of society tends to construct a hegemonic vision of male and female roles. In it, men occupy the public space (of greater relevance) and women the private space (of lesser relevance) (Yuval-Davis 1997, pp. 6-7). For Pateman (1988, p. 4), this differentiation of spaces allows us to understand how nationalisms and nations were discussed in the public sphere, dominated by men, relegating the private sphere, and thus women, to the background. Although the inclusion of women in the labor market, their emancipation and their irruption into the public sphere has meant that dependence on men has decreased, as a consequence, nationalism and masculinity have found a point of union (Chapman 2019). Moreover, as Iveckovic (1993) argues, the nation is feminine in terms of representation, as there is an urgent need to protect it, just as women are socially viewed. But in all other senses, the nation is symbolically masculine, because it must be defended and saved, and this is the social role of men in society.

The family is seen as an organizer of national history (McClintock 1993), where the central idea of nationalist construction is that of the home. It is here that gender relationsmasculinity and femininity - construct the essence of culture (Smith 2000, p. 362). This 
metaphorical household is headed by a man, and the woman acquires symbolic value as the mother of the nation or motherland (Nagel 1998, p. 254). Thus, as Eriksen (Eriksen 2017, p. 1442) states, hierarchical gender relations symbolically fuel aggressive nationalism.

Giving women value as the mother of the fatherland leads to an interest in women's reproductive control. This interest serves two purposes. The first is the maintenance of the nation for the reproduction of new members. The second is eugenics. This symbolic and patriarchal representation of women as mothers and reproducers of the nation carries with it an ethnic, class and cultural vision (Autumn and Marx 2005, p. 5). This is directly related to Chapman (2019) assertion that nationalism is closely related to the hatred of the different, which invites men, again, to take on the role of protector and provider of the nation, and women to take on the role of the perpetuator of the nation. In it, any woman who does not respond to the mandates of the motherland (lesbians, prostitutes, etc.) is labelled as unpatriotic. Moreover, this preoccupation with sexuality also responds to the fact that women are bearers of male honor (Nagel 1998, p. 256). In the political imagination, it is the conservative parties that defend pronatalism or the control of reproduction, marriage or sexuality, as opposed to the more progressive parties (King 1998, p. 48).

Thus, women are seen as the reproducers of nations, biologically, culturally and symbolically, through socialisation and traditions, and are even considered "guardians of culture". This is because socialisation and culture are transmitted mainly at home, in the private sphere, owned by women (Yuval-Davis 1997, pp. 78-83). According to Anthias and Yuval-Davis (1989, p. 7), women are crucial to national creation and reproduction in relation to five dimensions. First,

... women are considered the biological reproducers of the nation's members.

Secondly, they are the reproducers of the bonds within the nation's groups.

Third, they are the primary reproducers of ideologies and transmitters of culture through socialization. In Fourth place, they are the representation of national differences as the ideological symbol of the nation. Fifth, as participants in struggles concerning the nation.

Thus, in nationalist processes, "women are constructed as symbols of national 'essence', unity and emancipation as well as border guards of ethnic, national and racial difference" (Yuval-Davis 1997, p. 117). Walby (1992) added two new categories to those proposed by Anthias and Yuval-Davis: the division of labor and the work performed by women, both of which help to maintain social hierarchies.

Despite all of this, nationalism and feminism are closely connected, as both movements have helped and interacted with each other (Herr 2003). However, the feminist movement has generally been abandoned by nationalism after achieving its goals. For this reason, many activists within the feminist movement reject nationalism and opt for pluralistic, inclusive and liberating national projects, and dispense with the nation as a source of identity (Herr 2003; Villellas and Villellas 2007).

This masculinized construction of the nation is also reflected in welfare states, as they were built on a model of society based on the traditional family, which was based on two principles; that of maintenance, reserved for men as providers, and that of domestic and family care, which corresponded to women (Montagut 1996; Draibe and Riesco 2006; Orloff and Laperriere 2020). Several authors have recognized the fundamental role of gender relations in the structure and effects of the welfare state (Skocpol 1992; Lewis 1992; Sainsbury 1994, 1999; Orloff 1993, 1996; Orloff et al. 2003).

Furthermore, as Draibe and Riesco (2006) state, the elaboration of the classic typologies of welfare states created by Esping-Andersen (1993) "has privileged the state-market relationship, the economic, institutional and political dimensions and the processes of social stratification and decommodification of goods and services".

The feminist revision of Esping-Andersen (1993) approach also criticizes the absence of a gender perspective in the theorization of welfare states, considering that factors with a crucial weight and impact on national singularities have been omitted, such as ethical- 
cultural and ideological values, the social representation of femininity and masculinity, or the unequal sexual distribution of working time (Orloff 1996).

The lack of a gender perspective in the classic welfare state models theorised by Anderson (1993) has been analysed in the three elements that constituted them: (1) the relations between the state, market and family in order to provide the population with welfare; (2) the impact of the social state on social stratification; and (3) the decommodification of the workforce in terms of social and citizenship rights.

Firstly, regarding the relationship between the state, the market and the family in order to provide the population with welfare, it is considered that Andersen forgets the role of the family and, with it, the contribution of women, with unpaid work, through care and the provision of welfare which, due to structural inequality, relegates women to the private sphere. Therefore, the feminist movement is calling for the inclusion of the family-home-woman component (Martínez 2007; Lucas and Bayón 2017). Secondly, concerning the impact of the social state on social stratification, Andersen takes into account the inequalities originated by the capitalist system, but ignores the stratification caused by the sexual dimension. Hence, we find a dualistic model in terms of social protection, where the salaried man is granted all of the social rights and the woman the rights derived from her role within the family-wife and mother (Martínez 2007; Lucas and Bayón 2017) —or, as Orloff (2017) claims, welfare states shape gender relations. Thirdly, in relation to the decommodification of the workforce in terms of social and citizenship rights, it is considered that Esping-Andersen constructs the theory of Welfare States from a male perspective in which, in order to have social rights, it is necessary to be commodified, and therefore men are the main beneficiaries of them. If women want to have access to them, they must commodify themselves in order to obtain them, and thus have their work recognized and valued (Martínez 2007; Peterson 2009; Lucas and Bayón 2017).

Social protection systems thus emerge from a society marked by the sexual division of labour, in other words, from the power structure within families where providing is the responsibility of men, and domestic care is the responsibility of women (Draibe and Riesco 2006; Sainsbury 1999). Thus, different forms of welfare state contribute to social stratification and gender inequality (Hobson 1990; Jenson 1997; Knijn 1994; Lewis 1992; Mahon 2002; O'Connor 1993; Orloff 1993; Sainsbury 1999; Saraceno 1997; Shaver 1994; Williams 1995).

\section{Materials, Methodology and Analysis Strategy}

This paper starts from the consideration that all knowledge in this area is an important input to better analyse the project of nationhood and feminism among political parties and the factors that help to understand it. Thus, echoing the interest that this phenomenon has aroused, it makes a novel contribution by using the International Women's Day manifestos issued by five Spanish political parties in 2020 as an instrument of analysis. The year 2020 was chosen because it is the only year in which the parties with the largest representation in the Spanish congress prepared an $8 \mathrm{M}$ manifesto (previously, there were always some parties that did not do so).

The choice of these manifestos between Spanish political parties as an instrument of analysis of nationalism and feminism is justified, firstly, because they are the five parties with the largest representation in the Spanish Congress ${ }^{1}$. Secondly, this allows a comparative analysis between parties of different ideologies, and between ideologies themselves: on the one hand, between a progressive current (PSOE, IU and Podemos ${ }^{2}$ ) and a conservative one (VOX and PP); on the other hand, within each of the currents. Thirdly, it is justified because of the wealth of information in the manifestos. Through them we learn about the strategic lines of each political party in terms of the current of feminism with which it identifies, the gender perspective, the intersectionality of oppressions, the type of references to the Welfare State model, and the proposals for the struggle for equality and social protection policies. Fourthly, 
... the $8 \mathrm{M}$ manifestos reflect the ideology of each party with respect to this day, they are an instrument of political and ideological dissemination and, therefore, they allow us to approach the model of the State according to the conception or currents of feminism defended by each political party on the left and on the right wing.

The day $8 \mathrm{M}$, also declared by women's organisations as the "Day of Feminist Struggle" (Verdugo 2010, p. 268), was commemorated by the UN in 1975 with the aim of vindicating the rights of working women and the suppression of the inequalities suffered by women simply because they are women (Álvarez 1999). This commemorative date responds not only to the murder of women workers for demanding rights but also to the struggle and alliance between women - a product of the union of multiple social struggles-to obtain labour and political rights, a struggle led by trade unionists and suffragettes, but which responded to collective needs (Álvarez 1999; cited in Simón 2015, p. 4).

In Spain, the demonstrations held in the last two years were described as historic milestones due to their high turnout (EFE 2020). Thousands of women, led by feminist collectives and organisations related to the movement (Gracia 2020), took to the streets to claim their rights and demand equality between men and women. They demanded structural change to eradicate the inequalities suffered by women because they are women.

The strategy for the analysis of the manifestos includes two complementary approaches. On the one hand, each of them provides an account of the key terms related to women's roles, feminism and the national project of each party identified on the basis of the reference literature and research experience in this field. This approach makes it possible to identify which concepts acquire greater or lesser importance in the manifestos of each political party, and to analyze the differences and similarities between parties of different and of the same ideological sign. On the other hand, also in each of them, an adaptation of the coding protocol developed by Humlebaek and Ruiz (2018) is applied to analyze the political community.

The analysis by word count in the manifestos tries to capture the relationship of feminism with the national models shared by each, as analysed through the terms of feminism, equality, the conceptualization of women, references to the political party, $8 \mathrm{M}$, the conceptualization of men, the slogan of the party chosen for $8 \mathrm{M}$, regulations, references to Spain, references to other political parties, and feminist references. Thus, on the one hand, the conceptualization of women and men, feminism, equality, feminist references, $8 \mathrm{M}$ and regulations are concepts used by the different feminist currents in different ways. For example, within liberal feminism, the term "equality" (and not feminism) is normally used, and regulations are often referenced, while the radical current chooses to use the term "feminism". On the other hand, the references to the political party itself in the manifesto, to other parties, to the slogan chosen for $8 \mathrm{M}$, to Spain and to the Spanish nation, allow us to identify the ideology presented by each party-conservative or progressive-and the connection with feminism. For example, we think that conservative parties will use more references to the Spanish nation with no connection to feminism than progressive parties.

The adaptation of the coding protocol developed by Humlebaek and Ruiz (2018) is shown in the Table 1. As can be seen, based on it, we analyze the information in the manifestos using formal codes and substantive codes. The former refer to the authorship of the discourse (the political party and the party sector from which it is issued) and the latter delve into the communication dynamics around each party's national project and feminism through a set of measurement indicators designed for five dimensions. 


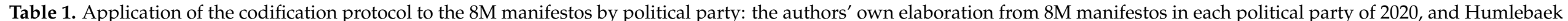
and Ruiz's codification protocol (Humlebaek and Ruiz 2018).

\begin{tabular}{|c|c|c|c|c|c|c|c|}
\hline CODE TYPE & DIMENSIONS & SUBDIMENSIONS & VOX & PP & PSOE & IU & Podemos \\
\hline Formal codes & $\begin{array}{l}\text { Origin of the } \\
\text { discourse }\end{array}$ & Area that issues the manifesto & Presidency & Presidency & Presidency & Gender Area & Gender Area \\
\hline \multirow{9}{*}{ Substantive codes } & \multirow{5}{*}{ Feminist current } & Identification with feminism & No & Yes & Yes & Yes & Yes \\
\hline & & Justification of inequality & Legally & Legally & $\begin{array}{c}\text { Legally } \\
\text { Patriarchal }\end{array}$ & $\begin{array}{l}\text { Legally } \\
\text { Patriarchal }\end{array}$ & $\begin{array}{l}\text { Legally } \\
\text { Patriarchal }\end{array}$ \\
\hline & & $\begin{array}{c}\text { State's Intervention as the only } \\
\text { way }\end{array}$ & Yes & Yes & Not solely & Not solely & Not solely \\
\hline & & $\begin{array}{l}\text { Gender roles as a way of } \\
\text { oppression }\end{array}$ & No & No & Yes & Yes & Yes \\
\hline & & $\begin{array}{l}8 \mathrm{M} \text { as a day for the feminist } \\
\text { struggle }\end{array}$ & No & Yes & Yes & Yes & Yes \\
\hline & \multirow{4}{*}{$\begin{array}{c}\text { Women and labor } \\
\text { rights }\end{array}$} & $\begin{array}{l}8 \mathrm{M} \text { as a key day in the fight for } \\
\text { women's labor rights }\end{array}$ & No & No & No & Yes & Yes \\
\hline & & $\begin{array}{l}\text { Identification of women as } \\
\text { workers }\end{array}$ & Yes & Yes & Yes & Yes & Yes \\
\hline & & Public and private distinction & No & No & Yes & Yes & Yes \\
\hline & & $\begin{array}{l}\text { Mentions of women's labor } \\
\text { rights }\end{array}$ & No & Yes & Yes & Yes & No \\
\hline
\end{tabular}


Table 1. Cont.

\begin{tabular}{|c|c|c|c|c|c|c|c|}
\hline CODE TYPE & DIMENSIONS & SUBDIMENSIONS & VOX & PP & PSOE & IU & Podemos \\
\hline & \multirow{6}{*}{ Intersecionality } & $\begin{array}{l}\text { Speaks about feminisms (in } \\
\text { plural) }\end{array}$ & No & No & No & Yes & Yes \\
\hline & & $\begin{array}{l}\text { Recognizes intersectionality of } \\
\text { oppressions }\end{array}$ & No & No & No & Yes & Yes \\
\hline & & $\begin{array}{l}\text { Proposes solutions for the } \\
\text { struggle for equality }\end{array}$ & Individual & Individual & $\begin{array}{l}\text { Individual and } \\
\text { global }\end{array}$ & $\begin{array}{l}\text { Individual and } \\
\text { global }\end{array}$ & $\begin{array}{l}\text { Individual and } \\
\text { global }\end{array}$ \\
\hline & & $\begin{array}{l}\text { Mentions to the oppression } \\
\text { endured by women }\end{array}$ & None & None & None & $\begin{array}{l}\text { Based on race, } \\
\text { ethnicity, sexual } \\
\text { identity, gender } \\
\text { identity, disability, } \\
\text { class, others }\end{array}$ & $\begin{array}{l}\text { Based on race, } \\
\text { ethnicity, sexual } \\
\text { identity, gender } \\
\text { identity, disability, } \\
\text { class, others }\end{array}$ \\
\hline & & $\begin{array}{l}\text { Establishes hierarchy of } \\
\text { oppressions }\end{array}$ & No & Yes & Yes & No & No \\
\hline & & Cause of oppressions & Individual causes & Individual causes & $\begin{array}{l}\text { Single individual } \\
\text { structure }\end{array}$ & $\begin{array}{c}\text { Interrelation of } \\
\text { different structures }\end{array}$ & $\begin{array}{c}\text { Interrelation of } \\
\text { different structures }\end{array}$ \\
\hline & \multirow{3}{*}{ Gender perspective } & References to the care system & No & No & No & Yes & Yes \\
\hline & & Demands structural change & No & No & $\begin{array}{l}\text { Only for some } \\
\text { structures }\end{array}$ & Yes & Yes \\
\hline & & $\begin{array}{l}\text { Recognizes women as the } \\
\text { political subject of the } \\
\text { movement }\end{array}$ & Both sexes & Both sexes & Both sexes & Yes & Yes \\
\hline
\end{tabular}


Table 1. Cont.

\begin{tabular}{|c|c|c|c|c|c|c|c|}
\hline CODE TYPE & DIMENSIONS & SUBDIMENSIONS & VOX & PP & PSOE & IU & Podemos \\
\hline & \multirow{5}{*}{ Welfare nationalism } & References to the welfare state & No & No & No & No & No \\
\hline & & Social protection policies & Yes & Yes & Yes & Yes & Yes \\
\hline & & Wealth redistribution & No & No & No & Yes & Yes \\
\hline & & Social stratification & No & No & No & Yes & Yes \\
\hline & & $\begin{array}{l}\text { Family as an economic } \\
\text { support for the country }\end{array}$ & Yes & Yes & No & No & No \\
\hline & \multirow{5}{*}{$\begin{array}{l}\text { Nationalism and } \\
\text { gender roles }\end{array}$} & $\begin{array}{l}\text { Reference to women's } \\
\text { reproductive ability }\end{array}$ & Yes & Yes & No & Yes & No \\
\hline & & To the country as home & Yes & No & No & No & No \\
\hline & & $\begin{array}{l}\text { Gender roles as reproductive } \\
\text { element of the nation }\end{array}$ & Yes & Yes & No & No & No \\
\hline & & Pronatalist Discourse & Yes & Yes & No & No & No \\
\hline & & $\begin{array}{c}\text { Manifesto reproduces national } \\
\text { identity }\end{array}$ & Yes & No & No & No & No \\
\hline
\end{tabular}


The categories of analysis presented in Table 1 are: feminist currents, intersectionality, women and labor rights, gender perspective, nationalism and gender roles, and welfare nationalism.

- $\quad$ Feminist currents: this category aims to analyse the feminist current with which each political party identifies. To this end, the key concepts or ideas of each feminist current are taken as a reference to determine the correspondence of the party with each of them. For example, in relation to the justification of inequality: liberal feminism will tend to do so legally, and radical feminism will do so structurally. In addition, this category of analysis analyses whether or not the party gives relevance to $8 \mathrm{M}$ as a day of feminist struggle.

- Intersectionality: this category is related to the previous one. The recognition of the intersectionality of oppression helps us to determine the feminist current with which each party identifies. Thus, the concept of the intersectionality of oppression within feminism corresponds to the third and fourth wave movements. This category also attempts to analyse whether the political party identifies different oppressions suffered by women (such as class oppression, which is characteristic of the demands of $8 \mathrm{M})$. This analysis can be linked to the welfare state.

- Women and labour rights: in this category we aim to identify whether or not the party recognises women as workers, fights for their labour rights, and differentiates between the public and private spheres in addition to examining the recognition of $8 \mathrm{M}$ as a key day in the struggle for women's labour rights.

- Gender perspective: this category aims to analyse whether the discourse, apart from trying to support the feminist movement, is also feminist or not. In other words, it is not only the ideas that are given in the discourse that matter, but also how they are said. The aim here is to analyse whether the discourse is feminist or not. Parties that present a gender perspective in their discourse will tend to be more favourable to women's rights.

- Nationalism and gender roles: this category aims to identify the discursive dynamics through which political parties construct the nation by differentiating between genders. The indicators analysed are based on the ideas put forward in the theoretical framework by the authors studied. Emphasis is placed on the differentiation of spaces granted to men and women, and the consequences that this entails (such as reproduction, social class, labour rights, etc.).

- Welfare nationalism: this category of analysis aims to analyse the identification of each political party with a welfare model. To this end, the degree of welfare that each party conveys in its discourse is analysed. The most relevant indicators in terms of gender are taken into account.

\section{Results}

This section presents the results obtained in two blocks. Firstly, those referring to the count of key terms related to women's roles, national projects and feminism in the five manifestos analyzed from the Spanish political parties on the occasion of $8 \mathrm{M}$; secondly, those referring to the adaptation of the coding protocol developed by Humlebaek and Ruiz (2018) for the analysis of the political community in each political party.

\subsection{Counting Analysis of the Key Terms in the 8M Manifestos}

In the following table we show the quantification of the key words identified in the $8 \mathrm{M}$ manifestos of each political party, in absolute terms (frequency of appearance) and relative terms (the percentage in terms of the total number of words in each manifesto). Based on these, we present a comparative analysis between the political parties and an individual analysis of each of them, highlighting the concepts with the greatest weight in the manifestos (women, men, feminism and equality), those that refer to national projects and political ideology (political party, references to another political party, references to Spain and regulations) and those that allude to the involvement and identification of the 
political party with $8 \mathrm{M}$ and feminism (the party slogan for $8 \mathrm{M}$, feminist references and $8 \mathrm{M}$ ) (see Table 2).

Table 2. Quantification of concepts, frequency of appearance and percentage according to the total number of words in each manifesto. Source: The authors' own elaboration from $8 \mathrm{M}$ manifestos from each political party.

\begin{tabular}{|c|c|c|c|c|c|c|}
\hline Indicators & VOX & PP & PSOE & Izquierda Unida & Podemos & Total \\
\hline $\begin{array}{l}\text { Total number of words in } \\
\text { the manifesto }\end{array}$ & 757 & 788 & 733 & 704 & 300 & 3.282 \\
\hline $\begin{array}{l}\text { Feminism/feminist } \\
\text { movement }\end{array}$ & $\begin{array}{c}1 \\
(0.001 \%)\end{array}$ & $\begin{array}{c}0 \\
(0.000 \%)\end{array}$ & $\begin{array}{c}5 \\
(0.007 \%)\end{array}$ & $\begin{array}{c}8 \\
(0.011 \%)\end{array}$ & $\begin{array}{c}7 \\
(0.023 \%)\end{array}$ & $\begin{array}{c}21 \\
(0.006 \%)\end{array}$ \\
\hline $\begin{array}{l}\text { Conceptualisation of } \\
\text { women }\end{array}$ & $\begin{array}{c}20 \\
(0.026 \%)\end{array}$ & $\begin{array}{c}22 \\
(0.0028 \%)\end{array}$ & $\begin{array}{c}19 \\
(0.026 \%)\end{array}$ & $\begin{array}{c}11 \\
(0.016 \%)\end{array}$ & $\begin{array}{c}4 \\
(0.013 \%)\end{array}$ & $\begin{array}{c}76 \\
(0.023 \%)\end{array}$ \\
\hline Regulations & $\begin{array}{c}0 \\
(0.000 \%)\end{array}$ & $\begin{array}{c}8 \\
(0.010 \%)\end{array}$ & $\begin{array}{c}2 \\
(0.003 \%)\end{array}$ & $\begin{array}{c}0 \\
(0.000 \%)\end{array}$ & $\begin{array}{c}1 \\
(0.003 \%)\end{array}$ & $\begin{array}{c}11 \\
(0.003 \%)\end{array}$ \\
\hline Name of political party & $\begin{array}{c}0 \\
(0.000 \%)\end{array}$ & $\begin{array}{c}5 \\
(0.006 \%)\end{array}$ & $\begin{array}{c}12 \\
(0.016 \%)\end{array}$ & $\begin{array}{c}6 \\
(0.009 \%)\end{array}$ & $\begin{array}{c}2 \\
(0.007 \%)\end{array}$ & $\begin{array}{c}25 \\
(0.008 \%)\end{array}$ \\
\hline References to Spain & $\begin{array}{c}8 \\
(0.011 \%)\end{array}$ & $\begin{array}{c}5 \\
(0.006 \%)\end{array}$ & $\begin{array}{c}1 \\
(0.001 \%)\end{array}$ & $\begin{array}{c}0 \\
(0.000 \%)\end{array}$ & $\begin{array}{c}2 \\
(0.007 \%)\end{array}$ & $\begin{array}{c}16 \\
(0.005 \%)\end{array}$ \\
\hline $\begin{array}{l}\text { References to other } \\
\text { political parties }\end{array}$ & $\begin{array}{c}6 \\
(0.008 \%) \\
\end{array}$ & $\begin{array}{c}1 \\
(0.001 \%)\end{array}$ & $\begin{array}{c}1 \\
(0.001 \%)\end{array}$ & $\begin{array}{c}0 \\
(0.000 \%)\end{array}$ & $\begin{array}{c}0 \\
(0.000 \%)\end{array}$ & $\begin{array}{c}8 \\
(0.002 \%) \\
\end{array}$ \\
\hline 8 March & $\begin{array}{c}1 \\
(0.001 \%)\end{array}$ & $\begin{array}{c}1 \\
(0.001 \%)\end{array}$ & $\begin{array}{c}4 \\
(0.005 \%)\end{array}$ & $\begin{array}{c}3 \\
(0.004 \%)\end{array}$ & $\begin{array}{c}4 \\
(0.0132 \%)\end{array}$ & $\begin{array}{c}13 \\
(0.004 \%)\end{array}$ \\
\hline Feminist referents & $\begin{array}{c}3 \\
(0.004 \%)\end{array}$ & $\begin{array}{c}0 \\
(0.000 \%)\end{array}$ & $\begin{array}{c}0 \\
(0.000 \%)\end{array}$ & $\begin{array}{c}1 \\
(0.001 \%)\end{array}$ & $\begin{array}{c}0 \\
(0.000 \%)\end{array}$ & $\begin{array}{c}4 \\
(0.001 \%)\end{array}$ \\
\hline 8M political party slogan & $\begin{array}{c}14 \\
(0.018 \%)\end{array}$ & $\begin{array}{c}1 \\
(0.001 \%)\end{array}$ & $\begin{array}{c}2 \\
(0.003 \%)\end{array}$ & $\begin{array}{c}2 \\
(0.002 \%)\end{array}$ & $\begin{array}{c}2 \\
(0.007 \%)\end{array}$ & $\begin{array}{c}24 \\
(0.007 \%)\end{array}$ \\
\hline Men (or referring to men) & $\begin{array}{c}12 \\
(0.016 \%)\end{array}$ & $\begin{array}{c}7 \\
(0.009 \%)\end{array}$ & $\begin{array}{c}4 \\
(0.005 \%)\end{array}$ & $\begin{array}{c}2 \\
(0.002 \%)\end{array}$ & $\begin{array}{c}0 \\
(0.000 \%)\end{array}$ & $\begin{array}{c}24 \\
(0.007 \%)\end{array}$ \\
\hline Equality & $\begin{array}{c}3 \\
(0.004 \%)\end{array}$ & $\begin{array}{c}15 \\
(0.019 \%)\end{array}$ & $\begin{array}{c}8 \\
(0.011 \%)\end{array}$ & $\begin{array}{c}1 \\
(0.001 \%)\end{array}$ & $\begin{array}{c}1 \\
(0.003 \%)\end{array}$ & $\begin{array}{c}28 \\
(0.009 \%)\end{array}$ \\
\hline $\begin{array}{l}\text { Total words on national } \\
\text { project and feminism }\end{array}$ & $\begin{array}{c}68 \\
(0.090 \%)\end{array}$ & $\begin{array}{c}65 \\
(0.082 \%)\end{array}$ & $\begin{array}{c}58 \\
(0.079 \%)\end{array}$ & $\begin{array}{c}34 \\
(0.048 \%)\end{array}$ & $\begin{array}{c}23 \\
(0.076 \%)\end{array}$ & $\begin{array}{c}250 \\
(0.076 \%)\end{array}$ \\
\hline
\end{tabular}

The first block of concepts includes the analysis of the terms: woman, man, feminism and equality. Of these, the most used by all parties in the $8 \mathrm{M}$ manifestos is the conceptualization of women. However, as the table above shows, this concept is mainly used by the conservative parties-PP (22) and VOX (20)—and by PSOE (19), as opposed to the more progressive parties, Izquierda Unida (11) and Podemos (4). PP, VOX and PSOE also include the conceptualization of man to a greater extent $(7,12$ and 4 respectively). They also use the concept of equality the most, and feminism or the feminist movement the least. For example, the PSOE uses the word equality 8 times while feminism is used only 5 times. In contrast, the parties furthest to the ideological left-Izquierda Unidad and Podemos-make no reference to men ( 1 and 0 , respectively), and the word feminism is the most used word in their $8 \mathrm{M}$ manifestos ( 8 and 7 , respectively).

The second block includes references to their own political party, to another political party, to Spain and to regulations. References to their own party are more frequent in progressive parties, with the PSOE being the most frequent, with 12 mentions. In contrast, there are references to other political parties, where VOX stands out with 6 mentions. Conservative parties also make more references to Spain in their speeches (VOX: 8; PP: 5), and to a lesser extent Podemos (2). In terms of regulations, it is the Partido Popular (8) that makes the most mentions, followed by the PSOE (2) and Podemos (1); Izquierda Unida and VOX do not mention any regulations. For example, the Partido Popular refers to the 
1978 Constitution and the State Pact against Gender Violence, and Podemos refers to the Law on Sexual Freedom.

The third block of concepts corresponds to the party's slogan for $8 \mathrm{M}$, feminist references and $8 \mathrm{M}$. The slogan chosen by each party is the most repeated concept throughout the manifesto, with VOX (14) making the most allusions, followed by IU, PSOE and Podemos, with 2 each. The content of the slogan chosen by each party has a strong ideological content. Thus, VOX's theme "No nos representan/No en mi nombre" ("They don't represent us/No in my name") makes a clear position against the feminist movement and the demands of 8M. Both the PP, with the slogan "Women above all", and the PSOE, whose slogan is "Free women, equal women", coincide in using the conceptualization of women in their slogans chosen for $8 \mathrm{M}$. As can be seen, the PSOE uses the concept of equality and not feministm, as Izquierda Unida and Podemos do: Izquierda Unida, with the slogan "Feminism in Struggle", and Podemos, with "United, free and feminists", choose to position themselves politically by using the conceptualization of feminism or feminist movement, and not equality. References to $8 \mathrm{M}$ are made to a greater extent by the progressive parties (Podemos: 4, IU: 3 and PSOE: 4) as opposed to the conservative parties (PP and VOX, with 1 mention each).

Only VOX (3) and IU (1) mention feminist referents (people, mainly women, whose contributions and struggles have been relevant to conceptualize, and who signify the feminist movement). These mentions are made with different intentions. On the one hand, VOX uses them to discredit the current feminist movement and, distorting the theory of the feminist references it names, to reject the gender perspective when they state that: "the women of the alternative are here to celebrate the legacy of Spaniards like Clara Campoamor, Concepción Arenal or Emilia Pardo Bazán, who taught us that our competences and capacities do not depend on gender" (VOX Spain, min: 6: 08). As can be seen, it mentions Spanish nationality to reaffirm and visualize on this day the patriotism and national identity that characterizes this party. On the other hand, Izquierda Unida uses Clara Zetkin as a referent of socialist feminism to support the feminist struggle, stating in its manifesto: "after so long, the legacy of socialist feminists like Clara Zetkin reminds us that feminism must be in struggle" (Izquierda Unida 2020, p. 1).

If we now analyze the concepts used by each political party in the $8 \mathrm{M}$ manifesto, VOX mentions the most politically charged ones as a way of visualizing its conservative character and differentiating itself from other parties, for example, woman, man, the slogan chosen for $8 \mathrm{M}$, Spain, and references to other political parties. Strategically, it also does so by being the party that names the most feminist references, in relation to the rest of the parties analyzed, with the intention of discrediting the feminist movement and without supporting, during its discourse, the thinking of the authors it names. Of the five parties analyzed, VOX is the only one that does not refer to its party in the manifesto, as it emphasizes its identity through its political slogan "not in my name or they do not represent us" in clear rejection of the demonstrations called on $8 \mathrm{M}$ and messages such as "those who make environmentalism their political banner that can only be defended by the left do not represent us" and "those who, under the pretext of freedom, try to impose a secular state that does not respect freedom of belief do not represent us" (VOX España 2020, chp. 9, p. 26). The party's strategy for $8 \mathrm{M}$ includes the same slogan-" represent us" - that was used by the 15M movement (Movimiento 15M 2013).

The PP clearly externalizes its identification with the liberal current of feminism. The concepts most frequently used in its manifesto are woman, man, equality and the mention of regulations about these topics. Mentions of Spain and the party itself also occupy a central place. However, the rest of the concepts go unnoticed throughout the manifesto, with the omission of the word feminism being of great relevance. In the PSOE, the words most used are the conceptualization of women, references to their party and the word equality. In its manifesto, it leaves concepts such as feminism or references to men in the background. The PSOE shows an intermediate position and makes a moderate use of all of the concepts mentioned, without major differences between them. 
The IU presents a different image in its manifesto. The key terms in the manifesto are women and feminism, followed by references to the party itself. We find other concepts such as $8 \mathrm{M}$, the conceptualization of men, and the slogan chosen for this day ("feminisms in struggle"). The more political terms (for example, regulations or references to Spain) are not relevant in the manifesto of this party.

Podemos has feminism, women and $8 \mathrm{M}$ as its priority concepts, the three most identified with the International Women's Day for which these manifestos are issued. It is the only party that makes reference to the Sexual Freedom Law, as it is considered a sign of political identity within its political program (Podemos 2020). In the analysis by word count, a certain similarity between Podemos and the conservatives stands out, as it makes strong references to the party itself, to the slogan chosen for this day, and to Spain. The successful strategy of Podemos in using the word "Spain" to mobilize its electorate has been demonstrated elsewhere. For example, on 31 January 2015, in the March for Change organized by Podemos in Madrid, its secretary general, Pablo Iglesias, quoted the word "patria" more than six times and "Spain" and "Spanish" up to sixteen times (Navarro 2020; Ruiz et al. 2020). The rest of the concepts analyzed go unnoticed due to their infrequent or lack of representation in this party's $8 \mathrm{M}$ manifesto, such as references to other political parties or references to men, with 0 mentions of both concepts, for example.

\subsection{Ways of Understanding the Nation from a Gender Perspective}

This section presents the results obtained after applying the adaptation of the coding protocol (Humlebaek and Ruiz 2018) to the $8 \mathrm{M}$ manifesto issued in 2020 by each political party. They are presented by blocks of political parties according to the similarities and differences found in the indicators designed to measure the model of nationhood and feminism, which are shown in Figure 1.

The first block of political parties is entitled "separated at birth, me to VOX and you to the PP". These two conservative parties present a very similar discourse, although VOX - unlike the PP-explicitly denies the existence of feminism and $8 \mathrm{M}$ as International Women's Day, nor does it consider it as a key day in the struggle for women's labour rights. For these parties, inequality is the product of individual behaviour, where state intervention is the only way to balance the scales. As far as the labour sphere is concerned, both identify women as workers and value the work they do, but they do not distinguish between the public and private spheres. The PP does mention women's labour rights, as shown in the following extract from its manifesto: "employment is one of the conditions that most indicate equality. We defend equal opportunities in access to the labour market and equal pay for women and men" (Partido Popular 2020, p. 3).

Furthermore, both manifestos lack a gender perspective and advocate a liberal discourse and the denial of different systems of oppression, as far as feminism is concerned. The discourse of these two conservative parties in their $8 \mathrm{M}$ manifestos presents a pronatalist and reproductive stance of the nation, even in the party slogan for $8 \mathrm{M}$ in the case of VOX ("not in my name/they do not represent us"). For these parties, the political subject of feminism is not women, but both sexes, and no structure of oppression is recognized.

However, when it comes to the idea of nationhood based on welfare states, we find differences. VOX has an affinity for a liberal welfare state, while the PP is more akin to the continental one. However, in both cases there is a commitment to family policies marked by the gender division in which women continue to be responsible for care. This difference between the genders is more explicit in VOX, which also displays a discourse that is more discriminatory towards women and denies the feminist movement. 


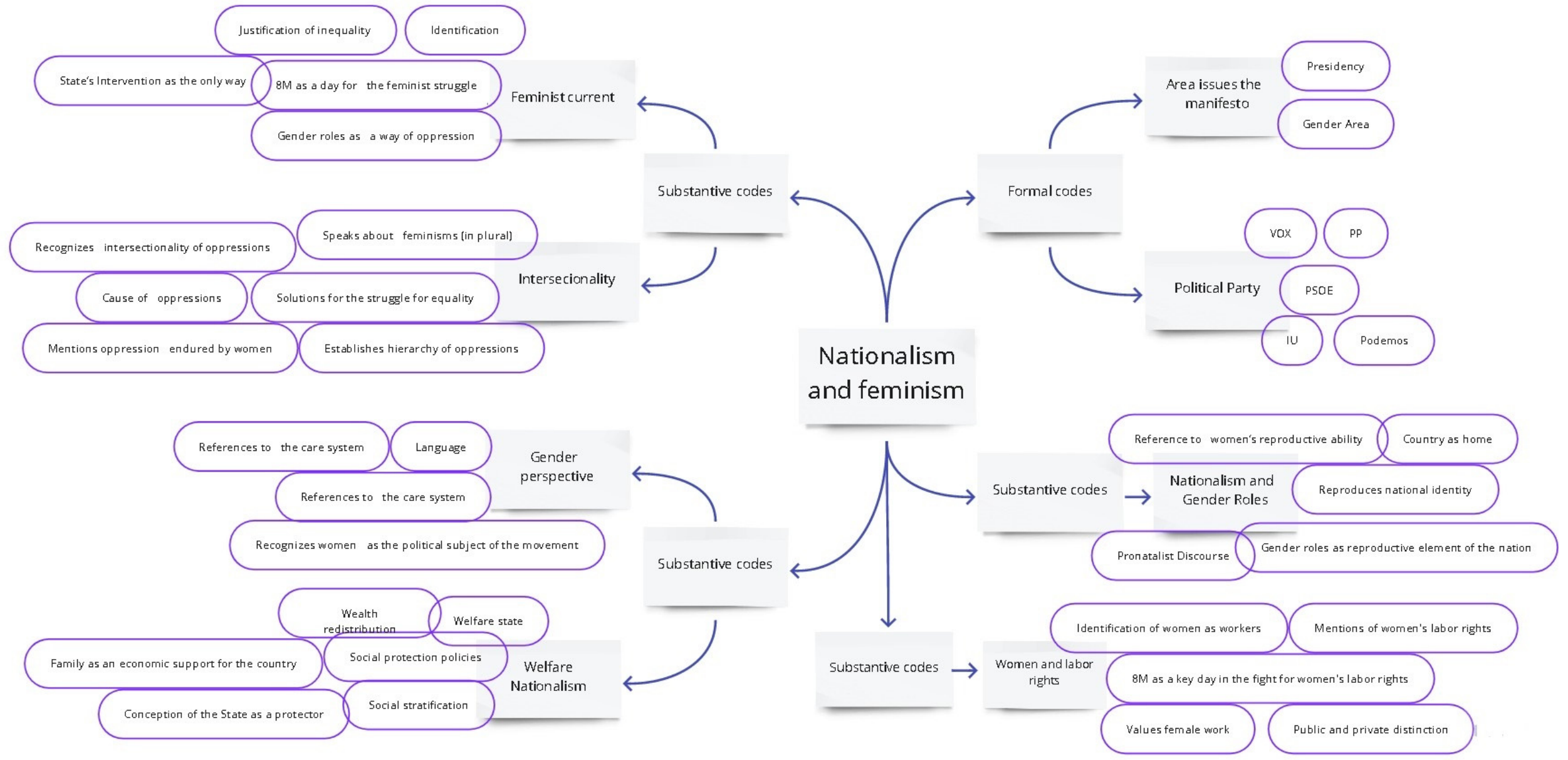

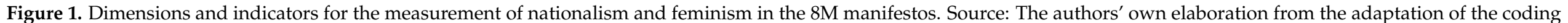
protocol developed by Humlebaek and Ruiz (2018). 
The second block, which includes the PSOE, is entitled "between two waters", because the analysis of its manifesto considers both sexes to be political subjects of feminism, and its discourse has hints of the liberal and socialist currents. It does not consider $8 \mathrm{M}$ as a key day in the struggle for women's labour rights, but it does mention women's labour rights (improving their working conditions and wages with RDL 6/2019 of 3 August). It also values women's work and distinguishes between the public and private spheres.

This political party considers that inequality is a product of the combination of individual and structural causes, and that gender inequality is a priority. It does not allude to different feminisms or to the intersection of oppressions. The discourse is not gendered and does not reproduce the nation through the manifesto. This political party reflects, in its 8M manifesto, a Mixed Welfare State, which is committed to a decommodification similar to that of the Social Democratic Welfare State and a low level of defamiliarization similar to that of the Continental Welfare State. In the manifesto it refers to a collective nationalism when it talks about the conquest of liberties by women. In addition, it makes several allusions to social rights and the struggle for equal social rights. However, there is some support for the division of roles, considering that discrimination is not only structural.

The group of parties composed of Izquierda Unida and Podemos we have called the "aliade bloc". These parties, which are the only ones that speak from the specific area of women's issues, have very similar characteristics: gender abolition and understanding care as a collaborative responsibility of society as a whole, and not as an obligation of women. Thus, they conceive of women as the political subject of feminism, and $8 \mathrm{M}$ as a day of the feminist struggle and a key day in the fight for women's labour rights. Both value women's work and differentiate between the public and private spheres. But only Izquierda Unida mentions women's labour rights:

“... we fight against the sexual division of labour (...) neoliberalism turns us into objects that can be exchanged in this global market that generates huge profits. From the IU we say enough to the commodification of our bodies (...) This economic system needs care which it suffocates, makes invisible and makes us fall back on us, women. Capitalism would collapse without the work we do to reproduce life. In Izquierda Unida we demand the universalisation of care based on co-responsibility with men and the State and on interdependence and eco-dependence". (Izquierda Unida 2020, pp. 1-2)

Izquierda Unida and Podemos identify the interrelation of different structural systems as the cause of oppression, which is why they recognize the existence and coexistence of different feminisms and propose structural change as the only way to equality. Both parties, from a gender perspective, do not reproduce the nation in their discourse, and identify with radical feminism with socialist overtones. Both parties advocate public, social protection and cooperation, terms that can be associated with the idea of social patriotism (Ruiz et al. 2017; Ruiz et al. 2020). These ideas, which emerge from the $8 \mathrm{M}$ manifestos of Podemos and Izquierda Unida, are in line with their policy of defending a social democratic welfare state model, with a high degree of decommodification and defamiliarization.

\section{Discussion and Conclusions}

The purpose of this paper was to offer evidence on the nation-building project and its construction based on the image projected by Spanish political parties in relation to women's roles. The starting point was a critical review of nations and welfare states as masculinized projects and, on this basis, to design a strategy based on the analysis of the manifestos issued by each political party in 2020 on International Women's Day. Through the analysis of the $8 \mathrm{M}$ manifestos, we have seen that there are notable differences between left-wing and right-wing parties, and between parties of the same ideologies.

As we have shown, nations, socially constructed from a male perspective, are reproduced through the discourses of political elites which were also strategically designed for International Women's Day. The two conservative parties analyzed, PP and VOX, show clear references to the way of understanding the relationship between the sexes and repro- 
duce the nation by basing their discourse on the different gender roles adopted by men and women; roles that place women in a situation of structural vulnerability when compared to men roles, and therefore not only reproduce the nation, but also inequality. The more progressive parties (IU and Podemos) have a universalist perspective with respect to the model of nationhood, and their discourse alludes to equality between the sexes.

The differences between the political parties are also marked in the conception of welfare nationalism across the manifestos analyzed. Although there are similarities, the differences here are more noticeable within parties with the same ideology. On the one hand, conservative parties identify with different welfare nationalisms. VOX, in its discourse, reflects characteristics of the liberal welfare state, with a high degree of commodification and familiarization. The PP, despite sharing these characteristics, does so in a more moderate way, so that its discourse resembles that of a Continental Welfare State. Both parties reproduce gender inequalities, as they place the heavy burden of care on women, relegating them, once again, to the private sphere. On the other hand, the progressive parties also present discrepancies. The PSOE identifies itself with a mixed welfare state, with a high degree of decommodification and a slight defamiliarization, as it continues to give women a large part of the burden of care and, therefore, also reproduces gender inequality. IU and Podemos reflect a high degree of defamiliarization and decommodification, and their manifestos are clearly feminist.

The lack of mention of laws or proposals in favour of women in the $8 \mathrm{M}$ manifestos (such as the sexual freedom law that Podemos mentions in its manifesto) is a clear example of the crisis in which institutionalised feminism in Spain finds itself. Since the beginning of democracy, there have been few laws on gender and equality. Those that do exist have not been modified to bring them up to date in line with the demands of a constantly moving society. There are many demands from feminist groups calling for public policies with a gender perspective where legislation takes into account the structural inequality between men and women. However, with globalisation and neoliberalism, state power is increasingly decentralised and outsourced. This is leading to the dismantling of the welfare state and to private companies overseeing the implementation of plans for equality. This has not only depoliticised women's groups but also reinvented patriarchy (Reverter 2011, pp. 225-28). As such, broadly speaking, we can say that institutionalised feminism is delegitimised, due to the dynamics that have been generated around the phenomena of globalisation and neoliberalism.

The analysis of the feminist current represented by each political party through the $8 \mathrm{M}$ manifesto has a clear connection with the ideas and measures disseminated through their electoral programs (Kohan 2019). In both cases, it reflects the ways in which conservative parties transmit a discourse of the reproduction of oppression and inequality between the sexes, in contrast to progressive parties that base their proposals on equity and social justice. The former not only tend to reproduce the nation with their discourses, but also the inequality between men and women, while the latter are committed to the universalist and anti-national ideology that they share under an egalitarian perspective, with proposals for the modification of laws that affect the feminist struggle in terms of prostitution, gender violence and surrogacy.

Both Podemos and IU (Unidas Podemos, a coalition formed by Izquierda Unida and Podemos) represent the most radical feminist discourse: there is a clear commitment to broaden the term "male violence", to change legislation in favor of greater protection for women and broader equality, for the care economy and for a return to the Welfare State. In this sense, they propose to protect care constitutionally, ending the wage gap and extending maternity and paternity leave, with the aim of making women independent of men and making the state the agent that sustains welfare. At the opposite extreme to these measures is VOX, with anti-feminist and gender violence denialist proposals, appropriating the slogan of the 15M movement, "they do not represent us", for International Women's Day. PP focuses on the State Pact to fight against gender violence, and stresses its natalist stance (Kohan 2019). The leitmotiv of PSOE from a gender perspective is to differentiate itself 
from the political right and also from Unidas Podemos, in order to occupy the ideological centre of Spanish politics. In its discourse there is a mixture of ideas that is reflected in considering both sexes as political subjects of feminism and presenting a discourse of the liberal and socialist current.

In short, this work has provided relevant information to advance in the understanding of the presence of different projects of nationhood and feminism among Spanish political parties of conservative and progressive ideology from a gender perspective. It has done so in a novel way by applying it to the manifestos of $8 \mathrm{M}$, an instrument of analysis that has proved to be powerful in continuing to reproduce an idea of nation constructed from a masculine vision and, in this way, favoring the persistence of inequality between the sexes and the fact that socially constructed and established dichotomies remain intact.

Supplementary Materials: The following are available online (manifestos issued by the five selected political parties): VOX (https:/ / www.youtube.com/watch?v=u_9Jar287QA), PP (http:/ / www.pp.es/sites/ default/files/documentos/20.03.08_declaracion_dia_internacional_de_la_mujer.pdf), PSOE (https:/ / www. psoe.es / media-content/2020/03/Manifiesto-PSOE.-D\%C3\%ADa-Internacional-de-las-Mujeres-2020 .pdf), Izquierda Unida (https: / / izquierdaunida.org/2020/03/05/feminismo-en-lucha-manifiestodel-area-de-la-mujer-de-iu-por-el-8m-de-2020/) and Podemos (https: / podemos.info/podemosapoya-las-movilizaciones-del-8m-2020/).

Author Contributions: Conceptualization, methodology, data curation, analysis, writing review and editing, L.N.A. and A.R.M. All authors have read and agreed to the published version of the manuscript.

Funding: This research received no external funding.

Institutional Review Board Statement: Ethical review and approval were waived for this study, due to the use of already published, secondary, anonymized information alone.

Informed Consent Statement: Not applicable.

Acknowledgments: We thank Ana Laura Peralta Novella for revising and for her amiability.

Conflicts of Interest: The authors declare no conflict of interest.

\section{Notes}

1 The parties' representation in the Congress of Deputies is: PSOE: 120 deputies; PP: 88 deputies; VOX: 52 deputies; Unidas Podemos (coalition of Izquierda Unida and Podemos): 35 deputies. Retrieved from http:/ / www.infoelectoral.mir.es/infoelectoral/min.

2 Although the two parties mentioned are integrated in the same organisation, they did not produce a joint $8 \mathrm{M}$ manifesto, but a separate one.

\section{References}

Al-Ali, Nayi. 2000. Review Article. Nationalisms, national identities and nation status: Gendered perspectives. Nations and Nationalism 6: 631-38. [CrossRef]

Álvarez, Ana I. 1999. Los orígenes y la celebración del día Internacional de la Mujer: 1910-1945. Oviedo: Universidad de Oviedo.

Anderson, Benedict. 1993. Comunidades imaginadas. Reflexiones sobre el origen y la difusión del nacionalismo. México: Fondo de Cultura Económica.

Anthias, Floya, and Nira Yuval-Davis. 1989. Introduction. In Woman Nation State. Edited by Nira Yuval-Davis and Floya Anthias. London: Palgrave Macmillan, pp. 1-15.

Autumn, Jessica B., and Myra Marx. 2005. Close your eyes and think of England: Pronatalism in the British Print Media. Gender E Society 19: 5-24. [CrossRef]

Bologh, Roslyn. 1990. Love or Greatness: Max Weber and Masculine-Thinking A Feminist Inquiry. London: Unwin Hyman.

Chapman, Annabelle. 2019. Donde el género se encuentra con el nacionalismo. Berlin Policy Journal. Available online: https: / / berlinpolicyjournal.com/where-gender-meets-nationalism/ (accessed on 5 November 2020).

Connell, Raewyn. 1995. Masculinities. Berkeley: University of California Press.

De Miguel, Ana. 2015. Neoliberalismo sexual. El mito de la libre elección. Valencia: Ediciones Cátedra.

Draibe, Sonia, and Manuel Riesco. 2006. Estado de bienestar, desarrollo económico y cuidadanía: Algunas lecciones de la literatura contemporánea. Chile: Comisión Económica para América Latina y el Caribe, Available online: https://dds.cepal.org/eventos/presentaciones/ 2006/0907/Sonia_Draibe_EstudiosCEPALMexico.pdf (accessed on 15 May 2020). 
EFE. 2020. El auge del movimiento feminista en cifras: De 1.000 asistentes en 2000 a la marcha de Madrid a los 375.000 en 2019. InfoLibre. Available online: https://www.infolibre.es/noticias/politica/2020/03/08/el_auge_del_movimiento_feminista_cifras_ 000_asistentes_2000_marcha_madrid_los_375_000_2019_104736_1012.html (accessed on 20 June 2020).

Eisentein, Zilliah, Sita Ranchod-Nilsson, and Mery Ann Tétrecault. 2000. Writing Bodies on the Nation for the Globe. Women, States and Nationalism. At Home in the Nation? Londond: Routledge.

Enloe, Cynthia. 1990. Bananas, Beaches, and Bases: Making Feminist Sense of International Politics. Berkeley: University of California Press. Eriksen, Thomas H. 2017. Sex, violence and nationalism. Ethnic and Racial Studies 40: 1438-49. [CrossRef]

Esping-Andersen, Gösta. 1993. Los tres mundos del Estado del bienestar. Valencia: Alfons el Magnànim.

Gracia, Marta. 2020. 8M: Las cifras que muestran la evolución de la mujer en la economía. ElPeriódico.com. Available online: https: / / byzness.elperiodico.com/es/economicos/20200308/8m-mujer-manifestacion-feminismo-dia-internacional-7877589 (accessed on 16 June 2021).

Greenfeld, Liah. 2005. Nacionalismo: Cinco vías hacia la modernidad. Madrid: Centro de Estudios Políticos y Constitucionales.

Hadjipavlou, María. 2006. No permission to cross: Cypriot women's dialogue across the divide. Gender, Place and Culture 13: 329-51. [CrossRef]

Herr, Ranjoo Seodu. 2003. The possibility of nationalist feminism. Hypatia 18: 135-60. [CrossRef]

Hobsbawn, Eric. 1988. Naciones y nacionalismo desde 1780. Barcelona: Crítica.

Hobson, Barbara. 1990. No Exit, No Voice: Women's Economic Dependency and the Welfare State. Acta Sociológica 33: 235-50. [CrossRef]

Humlebaek, Carsten, and Antonia M. Ruiz. 2018. La nación en España: Un instrumento de medida cualitativo para una cuestión compleja. Revista Española de Investigaciones Sociológicas 161: 141-56.

Iveckovic, Rada. 1993. Women, nationalism and war: Make love not war. Hypatia 8: 113-26.

Izquierda Unida. 2020. Feminismo en lucha. Manifiesto del Área de la Mujer de IU por el 8M de 2020. Available online: https: / /izquierdaunida.org/2020/03/05/feminismo-en-lucha-manifiesto-del-area-de-la-mujer-de-iu-por-el-8m-de-2020/ (accessed on 10 July 2021).

Jenson, Jane. 1997. Who cares? Gender and welfare regimes. Social Politics 4: 182-87.

Kandiyoti, Deniz. 2000a. Guest Editor's introduction. The awkward relationship: Gender and nationalism. Nations and Nationalism 6: 491-99. [CrossRef]

Kandiyoti, Deniz. 2000b. Walby, Gender, nations and states in a global area. Nations and Nationalism 6: 523-40. [CrossRef]

Kaufman, Joyce P., and Kristen P. Williams. 2017. Nacionalismo, ciudadanía y género. Oxford: International Studies Association and Oxford University Press, Available online: https:/ / oxfordre.com/internationalstudies/view/10.1093/acrefore/9780190846626.00 1.0001/acrefore-9780190846626-e-58 (accessed on 3 August 2021).

King, Leslie. 1998. France Needs Children: Pronatalism, nationalism and women's equity. The Sociological Quarterly 39: 33-52. [CrossRef]

Knijn, Trudie. 1994. Fish without bikes: Revision of the Dutch welfare state and its consequences for the (in) dependence of single mothers. Social Politics 1: 83-105. [CrossRef]

Kohan, Marisa. 2019. Igualdad y violencia de género: ¿qué propone cada partido en su programa electoral? Público.es. Available online: https:/ / www.publico.es/politica/elecciones-28a-igualdad-violencia-genero-propone-partido-programa-electoral.html (accessed on 13 April 2020).

Lepsius, Mario. 2004. The Nation and Nationalism in Germany. Social Research 71: 481-500.

Lewis, Jane. 1992. Gender and the Development of Welfare Regimes. Journal of European Social Policy 2: 159-73. [CrossRef]

Lucas, Jezabel, and Siro Bayón. 2017. Evolución del Estado de Bienestar desde una perspectiva de género. ¿Genealogía de una expropiación? El Futuro del Pasado 8: 147-95. [CrossRef]

Mackenzie, John M. 1987. The imperial pioneer and hunter and the British masculine stereotype in late Victorian and Edwardian times. In Manliness and Morality: Middle-Class Masculinity in Britain and America, 1800-940. Edited by James Mangan and James Walvin. Manchester: Manchester University Press, pp. 176-98.

Mahon, Rianne. 2002. Child care: Toward what kind of 'Social Europe'? Social Politics 9: 343-79. [CrossRef]

Márquez, Martha L. 2011. Perspectivas teóricas para abordar la nación y el nacionalismo. Papel Político 16: 567-95.

Martínez, Enric. 2002. From nation-building to building identification with political communities: Consequences of political decentralization in Spain, the Basque Country, Catalonia and Galicia, 1978-2001. European Journal of Political Research 41: 421-53. [CrossRef]

Martínez, María J. 2007. Las políticas familiares en Europa. Una aproximación al Estado de Bienestar desde un enfoque de género. Ph.D. thesis, Universidad del País Vasco-Euskal Herriko Unibertsitatea, Biscay, Spain.

McClintock, Anne. 1993. Family Feuds: Gender, Nationalism and the Family. Feminist Review 44: 61-80. [CrossRef]

McClintock, Anne. 1995. Imperial Leather: Race, Gender and Sexuality in the Colonial Contest. London: Routledge.

Montagut, Teresa. 1996. La mujer en el Estado de Bienestar. Un vacío teórico. In Dilemas del Estado de Bienestar. Edited by Fundación Argentaria-Visor. Madrid: Fundación Argentaria-Visor, pp. 405-20.

Mosse, George L. 1996. The Image of Man: The Creation of Modern Masculinity. New York: Oxford University Press.

Movimiento 15M. 2013. Las frases y lemas del Movimiento 15M más utilizados. Available online: http:/ / www.movimiento15m.org/ 2013/07 / las-frases-y-lemas-del-movimiento-15m.html (accessed on 10 April 2020). 
Nagel, Joane. 1998. Masculinity and nationalism: Gender and sexuality in the making of nations. Ethnic and Racial Studies 21: $242-69$. [CrossRef]

Navarro, Luis. 2020. La guerra de banderas asfixia al patriotismo cívico español. Infolibre. Available online: https://www.infolibre.es/ noticias/politica/2020/10/09/la_guerra_banderas_asfixia_patriotismo_civico_espanol_111911_1012.html (accessed on 22 June 2021).

O'Connor, Julia S. 1993. Gender, class and citizenship in the comparative analysis of welfarestate regimes: Theoretical and methodological issues. The British Journal of Sociology 44: 501-18. [CrossRef]

Orloff, Ann S. 1993. The Politics of Pensions: A Comparative Analysis of Britain, Canada and the United States, 1880s-1940. Wisconsin: UW Press.

Orloff, Ann S. 1996. Gender and the welfare state. Annual Review of Sociology 22: 51-70. [CrossRef]

Orloff, Ann S. 2017. Transforming Gendered Labor Policies in Sweden and the United States, 1960s-2000s. In Democracy and the Welfare State: The Two Wests in the Age of Austerity. Edited by Kessler-Harris and Maurizio Vaudagna. New York: Columbia University Press, pp. 249-73.

Orloff, Ann S., and Marie Laperriere. 2020. Políticas de bienestar y género. Ciudadanías. Revista de políticas sociales urbanas 1. Available online: http:/ / revistas.untref.edu.ar/index.php/ciudadanias/article/view/862/701 (accessed on 11 July 2021).

Orloff, Ann S., Elisabeth Clemens, and Julia Adams. 2003. Social theory, modernity, and the three waves of historical sociology. Working Paper Russell Sage Foundation 206: 1-99.

Partido Popular. 2020. Declaración del Partido Popular por el Día Internacional de la Mujer. Available online: http:/ / www.pp.es / sites/default/files/documentos/20.03.08_declaracion_dia_internacional_de_la_mujer.pdf (accessed on 10 July 2021).

Partido Socialista Obrero Español. 2020. 8 de marzo de 2020. Dia Internacional de las mujeres. Available online: https: / /www.psoe.es / media-content/2020/03/Manifiesto-PSOE.-D\%C3\%ADa-Internacional-de-las-Mujeres-2020.pdf (accessed on 10 July 2021).

Pateman, Carole. 1988. The Sexual Contract. Cambridge: Polity.

Pateman, Carole. 1989. The Disorder of Women: Democracy, Feminism and Political Theory. Stanford: Stanford University Press.

Peterson, Elin. 2009. Género y Estado de bienestar en las políticas españolas. Asparkia 20: 35-57.

Podemos. 2020. Podemos apoya las movilizaciones del 8M 2020. Available online: https://podemos.info/podemos-apoya-lasmovilizaciones-del-8m-2020/ (accessed on 10 July 2021).

Público. 2020. El 8M de 2020, el año de la revuelta feminista. Público.es. Available online: https://www.publico.es/sociedad/8m-2020 -ano-revuelta-feminista.html (accessed on 5 June 2020).

Reverter, Sonia. 2011. Los retos del feminismo institucional. Revista Internacional de Filosofía 4: 223-29. Available online: https: / / revistas.um.es/daimon/article/view/152311/134641 (accessed on 8 October 2019).

Ruiz, Antonia M., Luis Navarro, and Elena Ferri. 2017. Patriotas sociales. La izquierda ante el nacionalismo español. Papers 3: 421-48.

Ruiz, Antonia M., Daniel Romero, and Luis Navarro. 2020. Social patriotism: Populist glue for a multinational democracy. National Identities 22: 3-22. [CrossRef]

Sainsbury, Diane. 1994. Gendering Welfare States. London: Sage.

Sainsbury, Diane. 1999. Gender Equality and Welfare States. Oxford: Oxford University Press.

Sainsbury, Diane. 1999. Gender and Social-Democratic Welfare State. Gender and Welfare State Regimes. Oxford: Oxford University Press.

Saraceno, Chiara. 1997. Family change, family policies and the restructuring of welfare. In Family, Market and Community: Equity and Efficiencyin Social Policy. Edited by Patrick Hennessy and Mark Pearson. Paris: OECD, pp. 63-80.

Shaver, Sheila. 1994. Body rights, social rights and the liberal welfare state. Critical Social Policy 13: 66-93. [CrossRef]

Simón, Elena. 2015. Las olas del feminismo. Ágora. Espacio de formación feminista. Available online: https://ieg.ua.es/es/documentos/ boletines-2015/boletin-7/las-olas-del-feminismo.pdf (accessed on 10 October 2019).

Skocpol, Theda. 1992. Protecting Soldiers and Mothers. Cambridge: Belknap Press of Harvard University Press.

Smith, Anthony D. 2000. Nacionalismo y Modernidad: Un estudio crítico de las teorías recientes sobre naciones y nacionalismo. Madrid: Istmo.

Varela, Nuria. 2008. Feminismo para Principiantes. Barcelona: Ediciones B.S.A.

Verdugo, Vicenta. 2010. Desmontando el patriarcado: Prácticas policías y lemas del movimiento feminista en la transición democrática. Feminismo/s 16: 259-79. [CrossRef]

Villellas, Ana, and María Villellas. 2007. La confluencia entre nacionalismo, género y feminismo: ¿un análisis relevante para los conflictos y la construcción de la paz? Mujeres en Red. El periódico feminista. Available online: https://escolapau.uab.cat/img/ programas/alerta/articulos/07articulo046.pdf (accessed on 8 October 2019).

VOX España. 2020. Lectura del manifiesto \#NoHablesEnMiNombre Rocío Monasterio [Archivo de vídeo]. Available online: https: / / www.youtube.com/watch?v=u_9Jar287QA (accessed on 10 July 2020).

Walby, Sylvia. 1992. Mujer y nación. Revista Internacional de Sociología Comparada 33: 81-100. [CrossRef]

Walvin, James. 1987. Symbols of moral superiority: Slavery, sport and the changing world order, 1900-1940. In Manliness and Morality: Middle-Class Masculinity in Britain and America, 1800-1940. Edited by James Mangan and James Walvin. Manchester: Manchester University Press, pp. 242-60.

Williams, Fiona. 1995. Race/ethnicity, gender, and class in welfare states: A framework for comparative analysis. Social Politics 2: 127-59. [CrossRef]

Yuval-Davis, Nira. 1997. Gender \& Nation. London: SAGE Publications. 